\title{
Theoretical model of interactions between particle-associated and free-living bacteria to predict functional composition and succession in bacterial communities
}

\author{
Takeshi Miki*, Norio Yamamura \\ Center for Ecological Research, Kyoto University, Hiranocho, Kamitanakami, Otsu, Shiga 520-2113, Japan
}

\begin{abstract}
We examined the interactions between 3 hypothesized functional groups of heterotrophic bacteria: POC specialists, which use only particulate organic carbon (POC); free-living DOC specialists, which use only dissolved organic carbon (DOC); and generalists, which use POC when particle-associated and DOC when free-living. We focused on (1) competitive interactions for the use of POC and DOC, and (2) commensal interactions, whereby DOC is supplied by the enzymatic hydrolysis of POC by particle-associated cells. Using a simple model, we found that the quantity and quality of POC and DOC, and the balance between the rate of POC hydrolysis and the release of DOC determine the coexistence between generalists and the specialists in the bacterial community. Surprisingly, a high level of POC hydrolysis, which is an apparently commensal process of generalists, was found to exclude free-living DOC specialists from the community. These factors also determine the community dynamics during a shift in the supply of POC, as may occur during a phytoplankton bloom. This model predicts 3 possible patterns for the order of succession in the community composition, and 2 distinct directions in which the distribution of production within the free-living community could change. These diverse patterns would affect both the biogeochemical processes and the community dynamics at higher trophic levels.
\end{abstract}

KEY WORDS: Generalists · Competition · Commensalism $\cdot$ Hydrolysis $\cdot$ Bacterial production

\section{INTRODUCTION}

Particles and ambient water represent 2 distinct, extremely different habitats for bacteria in aquatic environments. Particle-associated and free-living bacteria often exhibit different physiological traits, as indicated by differences in production and growth (Unanue et al. 1992, Friedrich et al. 1999), ectoenzymatic activity (Karner \& Herndl 1992, Smith et al. 1992, Riemann et al. 2000), and kinetics of substrate uptake (Ayo et al. 2001). These observations support the hypothesis that some bacterial groups adapt to nutrientrich, particulate microhabitats ('particle specialists'; Riemann et al. 2000), whereas other groups adapt to nutrient-poor, ambient water ('free-living specialists').
Furthermore, it has been thought that these groups do not interact with each other in terms of nutrient availability and usage, because they use distinct energy sources, i.e. particulate organic carbon (POC) versus dissolved organic carbon (DOC). Recently, the application of new molecular methods has indicated that particle-associated and free-living bacteria belong to distinct phylogenetic groups (DeLong et al. 1993, Acinas et al. 1997, Crump et al. 1999), supporting the above hypothesis.

Other lines of evidence, however, indicate that particle-associated and free-living communities sometimes show common features in terms of phylogenetic composition (Hollibaugh et al. 2000, Riemann \& Winding 2001) and metabolic functions (Worm et al. 2001). 
This suggests the existence of 'generalists' that migrate between the particulate and water phases, using both POC and DOC as organic resources. Riemann \& Winding (2001) examined denaturing gradient gel electrophoresis (DGGE) profiles of bacterial communities during a diatom bloom. They found that several bands (species) were common to both the particleassociated and free-living fractions, even during a pre-bloom period in which low abundance of particleassociated bacteria suggested a low concentration of labile and available particles. It follows that these species use DOC during the pre-bloom period, whereas they use both DOC and POC after the bloom. This observation strongly suggests the existence of generalists. Riemann \& Winding (2001) also found that a number of major bands in the free-living fraction disappeared as the number of particles and particleassociated bacteria increased. This disappearance of some phylogenic types of free-living bacteria may be due to competitive exclusion in the ambient water. Furthermore, Kirchman (2002) has hypothesized that species in the Cytophaga-Flavobacteria cluster are possible members of such a generalist group (but see Fandino et al. 2001); members of this cluster are abundant in both particle-associated and free-living communities, and are able to use the high molecular mass fraction of dissolved organic matter (DOM) (Cottrell \& Kirchman 2000). If generalists do exist, they appear in both the particle-associated and free-living communities, and compete with other particle-associated and free-living bacteria for POC and DOC.

Studies of hydrolytic processes on particles do not support the hypothesis that particle-associated and free-living bacteria do not interact with each other for POC and DOC. Because hydrolytic activity on particle surfaces is high, but the rate of consumption of hydrolysate by particle-associated cells is often low ('uncoupled' hydrolysis), DOM is supplied from particles to the surrounding water (Smith et al. 1992, Grossart \& Simon 1998, Schweitzer et al. 2001, Grossart et al. 2003), resulting in increased production of the free-living assemblage (Friedrich et al. 1999, Grossart et al. 2003). In other words, there are commensal interactions, i.e. positive influences of particleassociated cells on free-living cells.

Therefore, hydrolytic processes and the existence of generalists are important factors determining the interactions between the particle-associated and freeliving communities. In other words, these 2 factors largely influence the composition and production distribution within both communities. However, the existence of generalists and their physiological traits remain poorly documented. It is also difficult to experimentally control parameters related to hydrolysis. Therefore, at present, theoretical approaches are use- ful for examining the potential roles of generalists and hydrolysis on the interactions among particleassociated and free-living bacteria, and for predicting the outcome in the community dynamics.

In this study, we used a simple theoretical model to analyze the dynamics of 3 hypothetical groups of bacteria in aquatic environments: POC specialists, DOC specialists, and generalists. We defined these groups based on the source of energy used by each group. POC (or DOC) specialists use only POC (or DOC), whereas the generalists use both POC and DOC. Simplifying assumptions were made to clarify the environmental conditions under which different groups of bacteria with different resource-use strategies would dominate in aquatic bacterial communities. We examined the predicted community dynamics during a shift in the supply of POC and DOC, such as may occur during a phytoplankton bloom. We found that various patterns were predicted for both the order of succession in the community composition and the changes in the distribution of production among functionally different groups. In particular, we demonstrate that the following parameters, which reflect the nature and quality of POC and DOC, influence these patterns through the behavior of generalists: (1) bacterial growth efficiency (BGE) using POC and DOC, (2) intensity of hydrolysis, and (3) DOC release rate from hydrolyzed POC.

\section{METHODS}

Model description. Definition of variables: A flow diagram of the model is shown in Fig. 1. We assumed 2 fractions as carbon sources: POC $\left(C_{\mathrm{P}}\right)$, and DOC $\left(C_{\mathrm{D}}\right)$. In addition, we defined 3 bacterial strategies for the use of energy sources: DOC specialists $(D)$, occurring only in the free-living fraction and consuming only DOC; POC specialists $(P)$, occurring in both the free-living and particle-associated fractions; and generalists $(G)$, occurring in both the free-living and particle-associated fractions. By definition, POC specialists consume only $\mathrm{POC}_{\text {; }}$ their cells multiply on particle surfaces and release their daughter cells to the surrounding water (Jacobsen \& Azam 1984, Friedrich et al. 1999, Kiørboe et al. 2002). These newly produced, free-living cells either quickly find and colonize fresh particles (Kiørboe et al. 2002) without consuming DOC or remain dormant in a 'seed-bank' role (Pernthaler et al. 1998) until they find new particles. We assumed that the particleassociated cells of generalists consume only POC, whereas the free-living cells consume only DOC. The limitation of bacterial growth by inorganic nutrients (Kirchman 2000) is not considered in this model system.

We defined 'aggregates' $\left(A_{\mathrm{P}}\right.$ and $A_{\mathrm{G}}$ ) as particles colonized by POC specialists or generalists, respectively. 


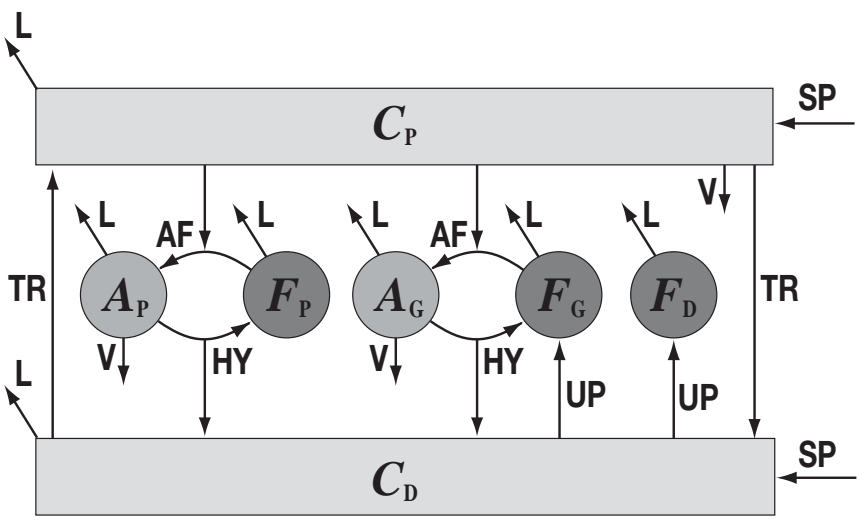

Fig. 1. Model flow diagram. $C_{\mathrm{P}}$ : POC, $C_{\mathrm{D}}$ : DOC, $A_{\mathrm{P}}$ : aggregates inhabited by POC specialists, $F_{\mathrm{P}}$ : free-living POC specialist cells, $A_{\mathrm{G}}$ : aggregates inhabited by generalists, $F_{\mathrm{G}}$ : freeliving generalist cells, $F_{\mathrm{D}}$ : free-living DOC specialist cells, AF: aggregate formation, HY: hydrolysis processes, UP: uptake of DOC, L: loss processes, V: vertical sinking, TR: transformation between POC and DOC, and SP: supply of organic carbon.

Recycling processes are not represented for simplicity

In other words, an aggregate consists of POC combined with the particle-associated fraction of POC specialists or generalists. We set $F_{\mathrm{D}}, F_{\mathrm{P}}, F_{\mathrm{G}}$ as free-living cells of DOC specialists, POC specialists, and generalists, respectively. Note that the units for POC and DOC are carbon concentration $\left(\mathrm{mgC}^{-1}\right)$ and the units for $F_{\mathrm{D}}, F_{\mathrm{P}}$, $F_{\mathrm{G}}, A_{\mathrm{P}}$, and $A_{\mathrm{G}}$ are densities of cells or aggregates $\left(\mathrm{l}^{-1}\right)$. Among these 7 components, we considered 3 main processes: (1) colonization of particles by free-living POC specialist and generalist cells, (2) hydrolysis of POC and subsequent processes, (3) consumption of DOC by freeliving generalists and DOC specialists. We constructed a simple box model that describes the interactions and dynamics among these 7 compartments.

Colonization of particles by free-living cells: We ignored heterogeneity among particles and assumed that every particle contains the same amount of carbon. The concentration of particles can then be calculated by dividing the POC concentration by the carbon content, i.e. $C_{\mathrm{P}} / \alpha$ (see Table 2 for definitions of variables and parameters). We assumed that either POC specialists or generalists, but not both, colonize each particle; thus, we considered competition between POC specialists and generalists for particles to colonize, and did not consider competition within one aggregate. For the free-living cells, we assumed that the rate of colonization of particles, i.e. the loss rate of freeliving cells due to colonization, is in proportion to the concentration of particles and the density of their freeliving cells. That is, we set the rate per cell to $a_{\mathrm{P}}\left(C_{\mathrm{P}} / \alpha\right)$ $\left(\mathrm{d}^{-1}\right)$ and $a_{\mathrm{G}}\left(C_{\mathrm{P}} / \alpha\right)\left(\mathrm{d}^{-1}\right)$, respectively. We assumed that sequential colonization stops and particles become an 'aggregate' after $n$ free-living cells colonize 1 particle. We assumed a fixed number of colonizers per particle (n), independent of bacterial density in the surrounding water. The rate of aggregate formation was $a_{\mathrm{P}}\left(C_{\mathrm{P}} / \alpha\right) F_{\mathrm{P}} / n$ and $a_{\mathrm{G}}\left(C_{\mathrm{P}} / \alpha\right) F_{\mathrm{G}} / n$ for POC specialists and generalists, respectively. The carbon content of bacteria per cell was $\beta$; therefore, the carbon content per aggregate was $\alpha+n \beta$ under this assumption.

Hydrolysis of POC and subsequent processes: For simplicity, we did not consider the population dynamics of bacteria on each aggregate, but took into account only the dynamics of the density of aggregates. We assumed that $n$ bacterial cells colonize each particle and consume it by hydrolysis at rate $h$ (i.e. the loss rate of aggregate $\left.\left[\mathrm{d}^{-1}\right]\right)$. Of the hydrolyzed carbon, the fraction $f_{\mathrm{F}}$ (the 'uptake ratio') is consumed by the colonizing bacteria for reproduction, and the fraction $f_{\mathrm{D}}$ (the 'release ratio') is released to the surrounding water as DOC. Released DOC enters the DOC pool $\left(C_{\mathrm{D}}\right)$, where it can be consumed by free-living cells of both generalists and DOC specialists. The remainder of the particulate carbon is converted to non-labile forms, so it follows that $0<f_{\mathrm{F}}+f_{\mathrm{D}}<1$ always holds. When each aggregate is completely consumed, the original colonizing cells and the newly reproduced cells are released to the surrounding water and enter the compartment of the free-living fraction of POC specialists $\left(F_{\mathrm{P}}\right)$ and generalists $\left(F_{\mathrm{G}}\right)$. The number of newly reproduced cells can be calculated as $e_{\mathrm{P}} \alpha f_{\mathrm{F}} / \beta$, where $e_{\mathrm{P}}$ is the growth efficiency of bacteria using POC. The unassimilated fraction of carbon $\left(1-e_{\mathrm{P}}\right) \alpha f_{\mathrm{F}}$ is converted to $\mathrm{CO}_{2}$ by bacterial respiration. Thus, the total number of cells released per aggregate is $n+e_{\mathrm{P}} \alpha f_{\mathrm{F}} / \beta$.

Consumption of DOC: We assumed that the specific growth rates of free-living generalist and DOCspecialist cells were $u_{\mathrm{G}} C_{\mathrm{P}}$ and $u_{\mathrm{D}} C_{\mathrm{P}}$ per cell $\left(\mathrm{d}^{-1}\right)$, respectively. Therefore, we can calculate the uptake rates of DOC by free-living generalists and DOC specialists as $e_{\mathrm{D}}^{-1} u_{\mathrm{G}} C_{\mathrm{D}} \beta F_{\mathrm{G}}$ and $e_{\mathrm{D}}^{-1} u_{\mathrm{D}} C_{\mathrm{D}} \beta F_{\mathrm{D}}$, respectively, where $e_{\mathrm{D}}$ is the growth efficiency of bacteria using DOC. Unassimilated carbon is converted to $\mathrm{CO}_{2}$ by respiration. Note that free-living POC specialist cells do not take up DOC.

Loss processes and other assumptions: We assumed that bacterial mortality is caused by predation and viral lysis, and that part of the lost bacterial biomass is recycled to the POC and DOC compartments (Nagata \& Kirchman 1991, 1992, Middelboe et al. 1996, Noble et al. 1999). The mortality rates per cell on aggregates and in the free-living cell compartment were defined as $m_{\mathrm{A}}$ and $m_{\mathrm{F}}$, respectively. Thus, the rate of carbon recycling in particle-associated and free-living cells to POC is $r_{\mathrm{P}} n \beta m_{\mathrm{A}}$ and $r_{\mathrm{P}} \beta m_{\mathrm{F}}$, respectively, where $r_{\mathrm{P}}$ is the common ratio of recycling to POC. Similarly, the rate of carbon recycling to the DOC compartment following the death of particle-associated and free-living cells is $r_{\mathrm{D}} n \beta m_{\mathrm{A}}$ and $r_{\mathrm{D}} \beta m_{\mathrm{F}}$, respectively, where $r_{\mathrm{D}}$ is the com- 
mon ratio of recycling to DOC. In addition, aggregates from which bacterial cells are removed return to the fresh particle compartment at the rate $\alpha m_{\mathrm{A}}\left(\mathrm{mgC} \mathrm{d}^{-1}\right)$. We also considered the loss of bacterial cells on aggregates by vertical sinking, at the rate $m_{\mathrm{V}}$. In this process, carbon from particles and particle-associated cells is completely lost from the system. We defined the loss rate of POC and DOC as $m_{\mathrm{P}}$ and $m_{\mathrm{D}}$, respectively. Some part of the carbon loss from each compartment is due to the conversion of POC to DOC and vice versa; those respective turnover rates were defined as $m_{\mathrm{P}} t_{\mathrm{PD}}$ and $m_{\mathrm{D}} t_{\mathrm{DP}}$, respectively. The remainder of the carbon loss is eliminated from the whole system, from either the POC or DOC compartment, at rates defined as $m_{\mathrm{P}}\left(1-t_{\mathrm{PD}}\right)$ and $m_{\mathrm{D}}\left(1-t_{\mathrm{DP}}\right)$, respectively. We assumed that these processes are driven by physical (e.g. transport, mechanical decomposition, aggregation) and chemical (e.g. photochemical reactions by UV) reactions. We set the additional loss of particles by vertical sinking at the rate $m_{\mathrm{V}}$, the same as the loss of aggregates. Finally, we assumed that POC and DOC are supplied by the autochthonous production of phytoplankton and/or allochthonous loads of suspended organic matter and dissolved organic matter at the rate $S_{\mathrm{P}}$ and $s_{\mathrm{D}}$, respectively.

Trade-offs for competition among specialists and generalists: In this model, we focused on competition between POC specialists and generalists for particle colonization, and between DOC specialists and generalists for DOC uptake. Because generalists are able to use both POC and DOC, there must be some trade-offs between specialists and generalists, both in the real world and in the model, to facilitate their coexistence. We assumed 2 trade-offs: (1) a trade-off between POC specialists and generalists, i.e. a higher colonization rate of POC specialists than generalists $\left(a_{\mathrm{p}}>a_{\mathrm{G}}\right.$ see Barbara \& Mitchell [2003] for colonization rates in different species), and (2) a trade-off between DOC specialists and generalists, i.e. higher uptake rate in DOC specialists than generalists $\left(u_{D}>u_{G}\right)$.
Mathematical analysis. Taking the processes and assumptions presented above into consideration, we developed equations relating the dynamics of the POC $\left(C_{\mathrm{P}}\right)$ and DOC $\left(C_{\mathrm{D}}\right)$ concentrations to the density of aggregates $\left(A_{\mathrm{P}}, A_{\mathrm{G}}\right)$ and of free-living cells $\left(F_{\mathrm{P}}, F_{\mathrm{D}}, F_{\mathrm{G}}\right.$ see Tables $1 \& 2$ ). For these equations, by introducing new symbols for the convenience of calculations (Table 3 ), and setting the right-hand side of all equations (Eqs. 1 to 7 ) to zero, we calculated the POC and DOC concentrations, and the bacterial carbon concentration of each fraction (i.e. the particle-associated POC specialists and generalists, and the free-living POC specialists, DOC specialists, and generalists) under steadystate conditions. There were 7 possibilities for the bacterial composition of the system at equilibrium: no bacterial groups using the defined energy sources present $\left(E_{\mathrm{N}}\right)$, POC specialists alone $\left(E_{\mathrm{P}}\right)$, generalists alone $\left(E_{\mathrm{G}}\right)$, DOC specialists alone $\left(E_{\mathrm{D}}\right)$, and 3 states of 2 groups coexisting with different strategies $\left(E_{\mathrm{GD}}, E_{\mathrm{GP}}\right.$, $\left.E_{\mathrm{PD}}\right)$. Note that 3 groups of bacteria using different strategies cannot coexist, because only 2 resources are available in the model system (generally, the number of coexisting species at equilibrium is not larger than the number of resources; Levin 1970). For all cases, the carbon concentration in each compartment at steady states is presented in Appendix 1.

Next, for each potential equilibrium, we analytically determined the conditions for the local stability using Ruith-Harbiz criteria (see Smith \& Waltman 1995). We then calculated numerically which equilibrium is locally stable, depending on the parameters. We showed numerically that only 1 of the 7 possible steady states is stable for any given set of parameters. This analysis permitted us to describe the composition of the bacterial community that would result, depending on the values of the parameters. In particular, we focused on the following parameters that reflect the nature and quality of POC and DOC: (1) BGE using POC and DOC, (2) intensity of hydrolysis, and (3) DOC release ratio from hydrolyzed POC.

Table 1. Model equations

$$
\begin{aligned}
& \mathrm{d} A_{\mathrm{P}} / \mathrm{d} t=\left(a_{\mathrm{P}} / n\right)\left(C_{\mathrm{P}} / \alpha\right) F_{\mathrm{P}}-h A_{\mathrm{P}}-\left(m_{\mathrm{A}}+m_{\mathrm{V}}\right) A_{\mathrm{P}} \\
& \mathrm{d} A_{\mathrm{G}} / \mathrm{d} t=\left(a_{\mathrm{G}} / n\right)\left(C_{\mathrm{P}} / \alpha\right) F_{\mathrm{G}}-h A_{\mathrm{G}}-\left(m_{\mathrm{A}}+m_{\mathrm{V}}\right) A_{\mathrm{G}} \\
& \mathrm{d} F_{\mathrm{P}} / \mathrm{d} t=\left(n+e_{\mathrm{P}} \alpha f_{\mathrm{F}} / \beta\right) h A_{\mathrm{P}}-a_{\mathrm{P}}\left(C_{\mathrm{P}} / \alpha\right) F_{\mathrm{P}}-m_{\mathrm{F}} F_{\mathrm{P}} \\
& \mathrm{d} F_{\mathrm{G}} / \mathrm{d} t=\left(n+e_{\mathrm{P}} \alpha f_{\mathrm{F}} / \beta\right) h A_{\mathrm{G}}-a_{\mathrm{G}}\left(C_{\mathrm{P}} / \alpha\right) F_{\mathrm{G}}+u_{\mathrm{G}} C_{\mathrm{D}} F_{\mathrm{G}}-m_{\mathrm{F}} F_{\mathrm{G}} \\
& \mathrm{d} F_{\mathrm{D}} / \mathrm{d} t=u_{\mathrm{D}} C_{\mathrm{D}} F_{\mathrm{D}}-m_{\mathrm{F}} F_{\mathrm{D}} \\
& \mathrm{d} C_{\mathrm{P}} / \mathrm{d} t=s_{\mathrm{P}}-(\alpha / n)\left(C_{\mathrm{P}} / \alpha\right)\left(a_{\mathrm{P}} F_{\mathrm{P}}+a_{\mathrm{G}} F_{\mathrm{G}}\right)-\left(m_{\mathrm{P}}+m_{\mathrm{V}}\right) C_{P}+t_{\mathrm{DP}} m_{\mathrm{D}} C_{D}+\left(\alpha+r_{\mathrm{P}} n \beta\right) m_{\mathrm{A}}\left(A_{\mathrm{P}}+A_{\mathrm{G}}\right)+r_{\mathrm{P}} m_{\mathrm{F}} \beta\left(F_{\mathrm{P}}+F_{\mathrm{G}}+F_{\mathrm{D}}\right) \\
& \mathrm{d} C_{\mathrm{D}} / \mathrm{d} t=s_{\mathrm{D}}+\alpha f_{\mathrm{D}} h\left(A_{\mathrm{P}}+A_{\mathrm{G}}\right)+t_{\mathrm{PD}} m_{\mathrm{P}} C_{\mathrm{P}}-m_{\mathrm{D}} C_{D}-e_{\mathrm{D}}^{-1} u_{\mathrm{G}} C_{\mathrm{D}}\left(\beta F_{\mathrm{G}}\right)-e_{\mathrm{D}}^{-1} u_{\mathrm{D}} C_{\mathrm{D}}\left(\beta F_{\mathrm{D}}\right)+r_{\mathrm{D}} m_{\mathrm{F}} \beta\left(F_{\mathrm{P}}+F_{\mathrm{G}}+F_{\mathrm{D}}\right)+r_{\mathrm{D}} m_{\mathrm{A}} n \beta\left(A_{\mathrm{P}}+A_{\mathrm{G}}\right)
\end{aligned}
$$


Table 2. Definitions of variables and parameters used in the model. Default values are based on literature data and values denoted by asterisk are hypothesized values

\begin{tabular}{|c|c|c|c|}
\hline Symbol & Definition & Unit & Default value \\
\hline \multicolumn{4}{|c|}{ Variables } \\
\hline$A_{\mathrm{X}}$ & Abundance of aggregate $(\mathrm{X}=\mathrm{P}, \mathrm{G})$ & particles $\mathrm{l}^{-1}$ & \\
\hline$F_{\mathrm{X}}$ & Abundance of free-living cells $(X=P, G, D)$ & cells $1^{-1}$ & \\
\hline$C_{\mathrm{P}}$ & Concentration of POC & $\mathrm{mg} \mathrm{l}^{-1}$ & \\
\hline$C_{\mathrm{D}}$ & Concentration of DOC & $\mathrm{mg} \mathrm{l}^{-1}$ & \\
\hline \multicolumn{4}{|c|}{ Parameters } \\
\hline$a_{\mathrm{X}}$ & Colonization rate to particles $(\mathrm{X}=\mathrm{P}, \mathrm{G})$ & particle $\mathrm{e}^{-1} \mathrm{~d}^{-1}$ & \\
\hline$u_{\mathrm{G}}$ & Specific growth rate of free-living generalists & $\mathrm{d}^{-1} /\left(\mathrm{mgC} \mathrm{l}^{-1}\right)$ & $0.2^{\mathrm{a}}$ \\
\hline$u_{\mathrm{D}}$ & Specific growth rate of free-living DOC specialists & $\mathrm{d}^{-1} /\left(\mathrm{mgC} \mathrm{l}^{-1}\right)$ & $0.3^{\mathrm{a}}$ \\
\hline$h$ & Hydrolysis rate of POC & $\mathrm{d}^{-1}$ & $0.5^{\mathrm{b}}$ \\
\hline$m_{\mathrm{A}}$ & Specific loss rate of particle-associated cell & $d^{-1}$ & $0.2^{\mathrm{c}, \mathrm{d}}$ \\
\hline$m_{\mathrm{F}}$ & Specific loss rate of free-living cell & $\mathrm{d}^{-1}$ & $0.2^{\mathrm{c}, \mathrm{d}}$ \\
\hline$m_{\mathrm{P}}$ & Specific loss rate of POC & $\mathrm{d}^{-1}$ & $0.1^{*}$ \\
\hline$m_{\mathrm{D}}$ & Specific loss rate of DOC & $\mathrm{d}^{-1}$ & $0.1^{*}$ \\
\hline$m_{\mathrm{V}}$ & Specific loss rate of aggregates and POC by vertical sinking & $\mathrm{d}^{-1}$ & $0.1^{*}$ \\
\hline$f_{\mathrm{F}}$ & Fraction of hydrolyzed POC consumed by bacteria & - & $0.3^{*}$ \\
\hline$f_{\mathrm{D}}$ & Fraction of hydrolyzed POC released as DOC & - & $0.3^{*}$ \\
\hline$e_{\mathrm{P}}$ & Growth efficiency on particle & - & $0.2^{\mathrm{e}}$ \\
\hline$e_{\mathrm{D}}$ & Growth efficiency in ambient water & - & $0.2^{\mathrm{e}}$ \\
\hline$t_{\mathrm{PD}}$ & Conversion ratio of POC to DOC & - & $0.1^{*}$ \\
\hline$t_{\mathrm{DP}}$ & Conversion ratio of DOC to $\mathrm{POC}$ & - & $0.1^{*}$ \\
\hline$r_{\mathrm{P}}$ & Recycled ratio of bacterial biomass to POC & - & $0.1^{*}$ \\
\hline$r_{\mathrm{D}}$ & Recycled ratio of bacterial biomass to DOC & - & $0.1^{*}$ \\
\hline$\alpha$ & Carbon content per particle & mgC particle ${ }^{-1}$ & \\
\hline$\beta$ & Carbon content of bacteria & $\mathrm{mgC} \mathrm{cell}^{-1}$ & \\
\hline$n$ & Number of bacterial cells per particle & - & \\
\hline $\mathrm{S}_{\mathrm{P}}$ & Supply rate of POC & $\mathrm{mgC} \mathrm{l}^{-1} \mathrm{~d}^{-1}$ & $0.4^{\mathrm{f}}$ \\
\hline $\mathrm{s}_{\mathrm{D}}$ & Supply rate of DOC & $\mathrm{mgC} \mathrm{l}^{-1} \mathrm{~d}^{-1}$ & $0.1^{\mathrm{f}}$ \\
\hline
\end{tabular}

Table 3. Model simplifications. Default values are hypothetical

\begin{tabular}{|lccc|}
\hline New symbol & Definition & Unit & Default value \\
\hline $\mathrm{P}$ & $C_{\mathrm{P}}$ & $\mathrm{mgC} \mathrm{l}^{-1}$ & - \\
$\mathrm{D}$ & $C_{\mathrm{D}}$ & $\mathrm{mgC} \mathrm{l}^{-1}$ & - \\
$\mathrm{A}_{\mathrm{x}}$ & $\beta n A_{\mathrm{x}}(\mathrm{X}=\mathrm{P}, \mathrm{G})$ & $\mathrm{mgC}^{-1}$ & - \\
$\mathrm{F}_{\mathrm{X}}$ & $\beta F_{\mathrm{X}}(\mathrm{X}=\mathrm{P}, \mathrm{G}, \mathrm{D})$ & $\mathrm{mgC}^{-1}$ & - \\
$k$ & $\alpha \beta^{-1} n^{-1}$ & & 100 \\
$a^{\prime}{ }_{\mathrm{P}}$ & $a_{\mathrm{p}} \beta^{-1} n^{-1}$ & & 2.5 \\
$a_{\mathrm{G}}$ & $a_{\mathrm{G}} \beta^{-1} n^{-1}$ & & 1.0 \\
& & & \\
\hline
\end{tabular}

Furthermore, we examined the dependence of community composition at equilibrium on POC and DOC, which are among the most important factors influencing the composition of the bacterial community (Riemann et al. 2000, Riemann \& Winding 2001, Selje \& Simon 2003). This permitted us to predict successional changes along the spatio-temporal variations in the supplies of POC and DOC, for example, under conditions of heterogeneous distribution of organic carbon in estuarine ecosystems, or with changes in carbon distributions during a phytoplankton bloom. In addition to changes in community composition, we also examined changes in the distribution of production of each bacterial group with changes in the supply rate of POC. Production rate was calculated by the concentrations of carbon and the density of bacteria at equilibrium. These analyses are based on the assumption that the composition and production are changing with the steady states of the system, during relatively slow changes in POC and DOC supply. This assumption is partly justified by the observation that the changes in the phylogenetic composition occurred rapidly, on a scale of 1 to $2 \mathrm{~d}$, during phytoplankton blooms (Pinhassi et al. 1999, Riemann et al. 2000, Fandino et al. 2001).

\section{RESULTS}

\section{Community composition at steady states and community succession}

A distinct community composition emerged, depending on various parameters reflecting the quality and quantity of carbon (Fig. 2). There were 5 patterns in composition, depending on the growth efficiency of 
bacteria (del Giorgio \& Cole 2000) using POC and DOC (Fig. 2a: D, P, G, GD, GP). Note that no bacteria could maintain populations in region $N$, where the quality of carbon was too low. This figure shows that high BGE for POC leads to the dominance of POC users (POC specialists and generalists; Regions $\mathrm{P}$ and $\mathrm{GP})$, whereas high BGE for DOC results in the dominance of DOC users (DOC specialists and generalists; Regions D and GD). Fig. 2a also shows that generalists are members of a community with a broad range of BGE values, but that a monoculture of generalists is realized over a smaller range (Region G in Fig. 2a), while coexistence with other specialists is realized over larger ranges (Regions GD and GP).

We next examined the effect of POC hydrolysis, which also reflects the quality of POC. Fig. $2 \mathrm{~b}$ shows the dependence of the bacterial community composition on the rate of POC hydrolysis $(h)$ and the rate of POC supply $\left(s_{\mathrm{P}}\right)$. Theoretically, increases in the rate of hydrolysis would have both positive and negative influences on DOC specialists: the supply of DOC released from aggregates increases with the rate of hydrolysis, enhancing the growth of DOC specialists (a)

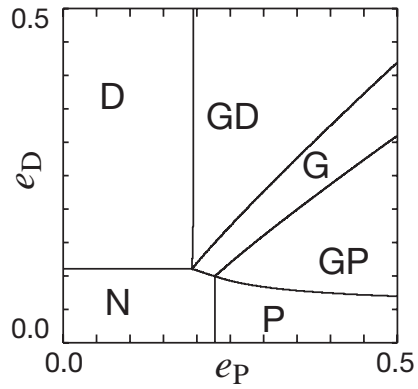

(c)

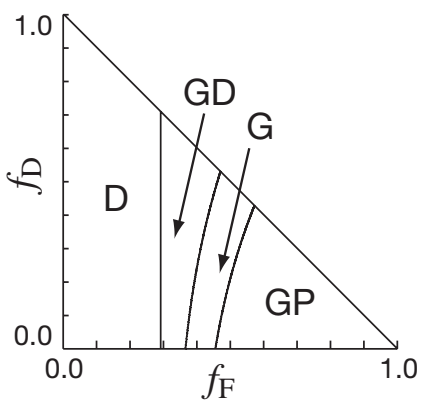

(b)

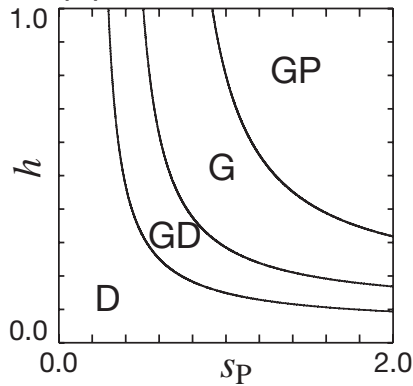

(d)

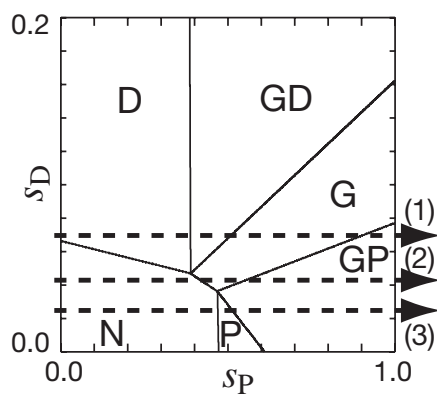

Fig. 2. Composition of the bacterial community as a consequence of variations in key parameters. The composition of species is denoted as follows: N: extinction of all 3 groups, D: dominance of DOC specialists, P: dominance of POC specialists, G: dominance of generalists, GD: coexistence of generalists and DOC specialists, GP: coexistence of generalists and POC specialists. Dashed arrows in (d) represent temporal changes in POC supply rate. Parameters were set as default values from Tables 1 \& 2 (the positive effect), but at the same time, increased hydrolysis leads to increased production of free-living generalists, resulting in more intense competition for DOC between free-living cells of DOC specialists and generalists (the negative effect). Therefore, the net effect on DOC specialists is intuitively unclear. This model revealed that it was negative (Fig. 2b); when the rate of hydrolysis is very high (Regions G and GP), DOC specialists are progressively excluded. In contrast, when the rate of hydrolysis is low (Region D), which reflects the low quality of particles, DOC specialists, which take up DOC more rapidly than generalists, have a better strategy than generalists that use both DOC and POC, resulting in the competitive exclusion of generalists. Therefore, the coexistence between DOC specialists and generalists is realized only at intermediate levels of the hydrolysis rate (Region GD).

Furthermore, Fig. 2c shows that a different community composition emerges, even when the total hydrolysis rate $(h)$ is constant, depending on the variable partitioning of hydrolyzed $\mathrm{POC}$, i.e. the fraction of the hydrolyzed carbon taken up by particle-associated cells (uptake ratio: $f_{\mathrm{F}}$ ) and the fraction released to the surrounding water as DOC (DOC release ratio: $f_{\mathrm{D}}$ ). In particular, the uptake ratio by particle-associated cells strongly influences community composition. The increase in the uptake ratio leads to the exclusion of DOC specialists because of increased competition for DOC by increased production of free-living generalists. In contrast, the release ratio to DOC has less of an influence on composition. An increased DOC release ratio does not exclude generalists, because increased DOC supply is used by both DOC specialists and generalist free-living cells, and does not change the competitive relationship between them.

Finally, we examined the dependence of the community composition on the rates of supply of POC and DOC in order to predict successional patterns when there is a shift in the organic carbon supply rate (Fig. 2d). We made the simplifying assumption that the rate of supply of POC $\left(s_{\mathrm{P}}\right)$ increases during phytoplankton blooms, while the rate of supply of DOC $\left(s_{\mathrm{D}}\right)$ remains fixed. The results show 3 successional patterns with an increasing POC supply rate, depending on the supply rate of DOC. When the DOC supply rate is not limiting (dashed arrow [1] in Fig. 2d), the basic order of succession is (1) DOC specialists only (Region D), (2) the emergence of generalists and their coexistence with DOC specialists (Region GD), (3) the disappearance of DOC specialists (Region G), and (4) the emergence of POC specialists and their coexistence with generalists (Region GP). When the rate of supply of DOC is limiting, DOC specialists cannot maintain their population and 2 patterns of succession 

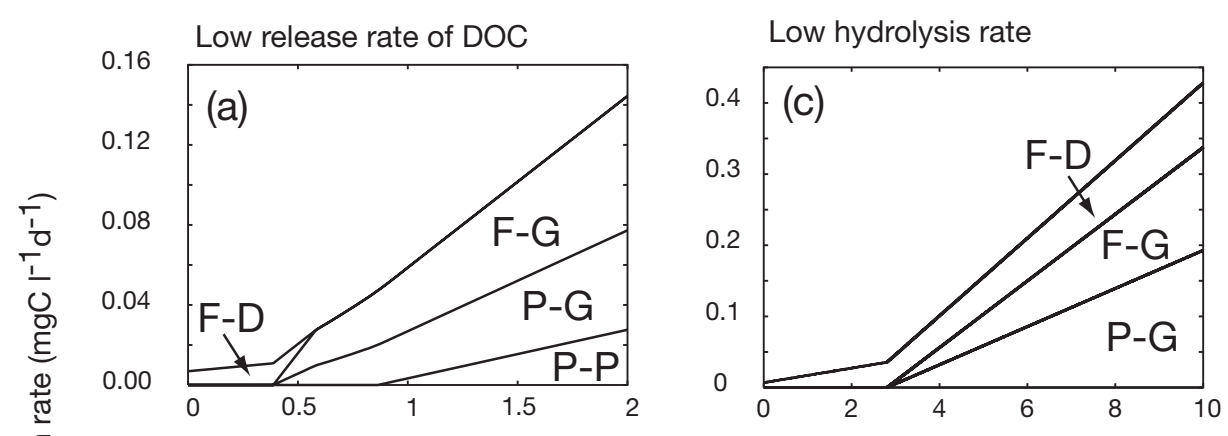

High release rate of DOC

High hydrolysis rate
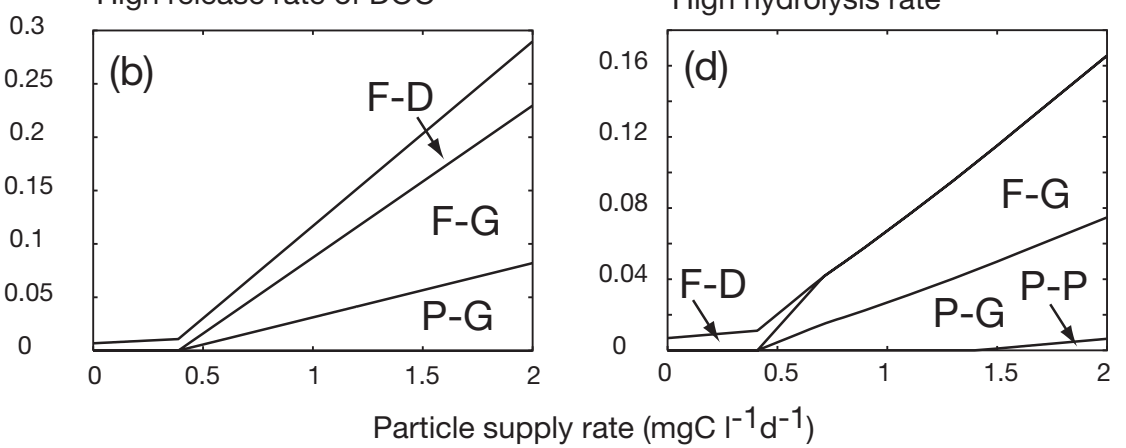

Fig. 3. Changes in the distribution of bacterial production with increasing POC supply, showing the production of the groups using each strategy. F-D: production of free-living DOC specialists, F-G: production of the free-living fraction of generalists, P-P: production of the particle-associated fraction of POC specialists. Parameter values: (a) $f_{\mathrm{F}}=0.3, f_{\mathrm{D}}=0.2$, (b) $f_{\mathrm{F}}=0.3, f_{\mathrm{D}}=0.7$, (c) $h=0.08$, (d) $h=0.45$. Other parameters were set as default values from Tables $1 \& 2$

develop. When the DOC supply rate is intermediate (dashed arrow [2] in Fig. 2d), generalists emerge earlier than POC specialists. However, when the DOC supply rate is very low (dashed arrow [3] in Fig. 2d), POC specialists emerge earlier than generalists. Similarly, the order of succession with increasing rates of supply of DOC depends on the rate of supply of POC. Furthermore, even in the more realistic case, in which both POC and DOC supplies change during the bloom, we can predict the successional order if the temporal patterns of POC and DOC supply are known.

\section{Effects of particle abundance on the distribution of bacterial production}

Next, we examined the effects of particle abundance on the distribution of bacterial production, i.e. the production rate of each bacterial group. We can qualitatively predict the changes in bacterial production that occur in response to spatio-temporal variations in the POC supply rate. The effects of DOC abundance on the structure of bacterial production are relatively simple and, therefore, are not shown here.

The production of particle-associated cells is expected to increase with increasing POC supply rates, and this proved to be true in the model (Fig. 3). Similarly, the total production of the free-living fraction (F-D + F-G, Fig. 3) was shown to always increase with increasing POC supply rates, regardless of the values set for the other parameters (Fig. 3). This is probably because increases in POC lead to increases in the DOC released from aggregates, resulting in the increased production of free-living cells, regardless of whether the DOC is used by generalist or by DOC specialist cells.

However, increasing the rate of POC supply changes the distribution of production in the free-living fraction of the community in different ways, depending on other factors (Fig. 3). For example, the production of DOC specialists (F-D) decreases with increasing POC supply when the fraction of hydrolysate released to the water $\left(f_{D}\right)$ is low (Fig. 3a), whereas the production of DOC specialists increases when the DOC release rate is high (Fig. 3b). In contrast, the production of DOC specialists (F-D) increases with increasing POC supply when the rate of hydrolysis (h) is low (Fig. 3c), but decreases with increasing POC supply when the hydrolysis rate is high (Fig. 3d). In all cases, the production of generalists (F-G) increases with the POC supply.

Note that increasing POC supply rates always have both positive and negative effects on the production of 
DOC specialists through interactions with generalists. By hydrolyzing POC, the generalists increase the supply of DOC to DOC specialists; however, the concomitant increase in the production of free-living generalist cells results in increased competition. Our model suggests that the net effect on DOC specialists shifts from negative to positive when the DOC release rate increases (compare Fig. 3a with 3b) or when the rate of hydrolysis decreases (compare Fig. 3d with 3c). Similarly, numerical calculations with equilibrium values of organic carbon and bacterial biomass demonstrated that the net effect of increased POC supply on DOC specialists shifts to positive when the BGE for DOC $\left(e_{\mathrm{D}}\right)$, recycling ratio to DOC $\left(r_{\mathrm{D}}\right)$, or mortality rate on aggregates $\left(m_{\mathrm{A}}\right)$ increase. In contrast, the net effect becomes negative when the uptake ratio of hydrolyzed POC $\left(f_{\mathrm{F}}\right)$, the BGE for POC $\left(e_{\mathrm{P}}\right)$, or carbon content per particle per bacterial carbon $(\alpha / n \beta)$ increase. Moreover, some factors are neutral, i.e. the net effect of changes in the POC supply remains the same, despite changes in the ratio of recycling to POC $\left(r_{\mathrm{P}}\right)$ or in the rates of physical and chemical conversion between POC and DOC ( $t_{\mathrm{PD}}$ and $\left.t_{\mathrm{DP}}\right)$.

\section{DISCUSSION}

\section{Interactions among generalists and specialists through hydrolysis}

Similarities between the phylogenetic composition of particle-associated and free-living bacterial communities have recently been shown, drawing increased attention from microbial ecologists to the existence of generalists; their ecological roles, however, remain unclear. Moreover, although the hydrolysis processes on aggregates have been intensely studied in recent years, the effects on the total bacterial community, including both free-living and particleassociated fractions, remain unclear. In the present study, we defined POC specialists, DOC specialists, and generalists, and used a theoretical model to examine how interactions among bacterial groups with these 3 strategies determine the composition of the bacterial community and the distribution of secondary production by bacteria. Our model demonstrated that the outcome of interactions depends on the supply and the quality (BGE, hydrolysis rate, and DOC release ratio from aggregates) of POC and DOC. When the supply or quality of the common resource increases, generalists are able to coexist with their competitors; large supplies and high quality of DOC tend to allow coexistence with DOC specialists, and large supplies and high quality of POC tend to allow coexistence with POC specialists (Fig. 2). In contrast, when the supply and quality of the resource used only by generalists increase, coexistence with the competitor is not favored; larger supplies and higher quality of DOC, for example, lead to the exclusion of POC specialists (Fig. 2). However, for the interactions between generalists and DOC specialists, this is not always true, because the effects of POC hydrolysis by generalists on DOC specialists are not straightforward.

The interactions between the 2 groups are commensal as well as competitive, and hydrolysis and the subsequent processes are involved in both competitive and commensal interactions. The production of new, free-living, generalist cells by using hydrolyzed POC has a negative, competitive effect on DOC specialists; thus, a high ratio of hydrolyzed POC used for production of new cells $\left(f_{\mathrm{F}}\right)$ favors the generalists. In contrast, the release of hydrolyzed POC as DOC has a positive, commensal effect on DOC specialists. Thus, when the DOC release ratio $\left(f_{\mathrm{D}}\right)$ is high, the commensal interaction prevents the exclusion of DOC specialists. This also enables the coexistence of the 2 groups, even when the supply of POC, which is used directly only by generalists, increases (Fig. 3b), implying that DOC specialists are not out-competed by generalists. Zissi \& Lyberatos (2001), using a mathematical model and a chemostat experiment, obtained similar results, showing that interactions with both competitive and commensal components enable the coexistence of 2 bacteria that cannot coexist in an exclusively competitive relationship. Note that a commensal interaction also exists between generalists and POC specialists: POC specialists supply DOC to free-living generalists. However, the increased supply of DOC indirectly intensifies the competitive interactions for $\mathrm{POC}$, so that the commensal interaction does not facilitate coexistence.

In addition, increases in the total hydrolysis rate $(h)$ lead to increases in both the DOC release $\left(f_{\mathrm{D}} h\right.$; commensal) and the production of free-living generalist

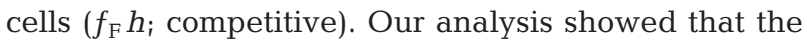
net effect of increased hydrolysis on DOC specialists is negative and results in the exclusion of DOC specialists (Fig. 2b). Increases in the hydrolysis rate lead to increases in both resource availability (DOC) and reproduction rate (of free-living cells) for generalists (by direct uptake of hydrolysate). However, increases in the hydrolysis rate result only in increases in resource availability (DOC) for DOC specialists, without affecting their reproduction directly. The net negative effect of increased hydrolysis on DOC specialists can probably be attributed to competition between DOC specialists and increasing numbers of free-living POC-DOC generalists for the fraction of hydrolysate released as DOC. 


\section{Simplicity of our model}

We made several assumptions to justify the simplification of our model formulations. (1) We assumed that aggregate formation rate was in proportion to the densities of particles and free-living bacterial cells (i.e. simple mass reaction). Although encounter rates are influenced by particle size or by swimming strategies of bacteria (Kiørboe \& Jackson 2001), we did not focus on the heterogeneity in the morphologies of particles or species-specific differences in chemotoxis. Therefore, a simple encounter rate is suitable for the predictions we made. (2) A simple linear, non-saturating uptake function of DOC was assumed. The introduction of a saturating function would not change the competitive interactions among specialists and generalists at steady states. (3) Trade-offs among specialists and generalists were assumed. There are actually various types of trade-offs and differences among specialists and generalists, e.g. the differences in hydrolysis rate or in growth efficiency using POC and DOC. However, the essential point is that of the existence of trade-offs between specialists and generalists, and additional numerical calculations showed that qualitative predictions were not changed under the different types of trade-offs. (4) Another critical assumption was the first order approximation for POC and DOC loss rate due to physical or chemical processes. One of our results showed that loss processes of POC and DOC did not change the patterns of production distribution. This indirectly suggested that these processes do not critically influence the interactions among specialists and generalists, and that the assumed simple loss rate is sufficient for our theoretical investigation.

\section{Testable predictions from this model}

Consideration of the interactions among DOC specialists, generalists, and POC specialists provides testable predictions regarding (1) the successional order of functional composition, and (2) changes in the distribution of bacterial production concurrent with the spatio-temporal variation in POC supply rate.

This is the first theoretical work predicting the successional order of bacterial community composition. When particle abundance increases, e.g. during a phytoplankton bloom, the successional order depends on the DOC supply rate. In the basic pattern, produced when the DOC supply rate is not limiting, the order of emergence of each group is: (1) DOC specialists, (2) generalists, and (3) POC specialists. We predicted that the emergence of POC specialists follows the emergence of generalists, which is consistent with the later emergence of 'particle specialists' in studies by
Riemann \& Winding (2001) of community dynamics during an induced phytoplankton bloom. However, our model also predicted that when the DOC supply rate is very low, POC specialists emerge before generalists. In fact, because the POC and DOC supply rates change simultaneously during phytoplankton blooms, the successional order may differ from the above predictions, which are based on an assumption of a fixed DOC supply rate. However, even in that case, we can predict the successional order from the composition patterns produced by changes in the POC and DOC supply rates.

The prediction that bacterial production in both the particle-associated community and the free-living community is enhanced by increased POC supply is very intuitive. Increased supplies of DOC from the hydrolysis of aggregates supports increased production in the free-living community. In the particleassociated community, the model predicted that both POC specialists and generalists would increase production. The patterns of change in the production distribution within the free-living community are different; both generalists and DOC specialists increase production, or DOC specialists decrease production while generalists increase production. In our model, we clarified the factors that can explain these opposite effects of increased POC on production in the freeliving fraction. The balance of competitive and commensal interactions between generalists and DOC specialists is important for determining the pattern of changes in production. When the quality of POC is high, as reflected by a high hydrolysis rate $(h)$, high growth efficiency $\left(e_{\mathrm{P}}\right)$, and high carbon content of particles $(\alpha / n \beta)$, the net interaction is competitive, and the production of DOC specialists will decrease with increasing particle supply. Selectively low mortality in particle-associated cells $\left(m_{\mathrm{A}}\right)$ also leads to decreases in the production of DOC specialists with increasing particle supply. In contrast, when hydrolysis is highly uncoupled with bacterial growth (high $f_{\mathrm{D}}$ and low $f_{\mathrm{F}}$ ), and when the quality of DOC $\left(e_{\mathrm{D}}\right)$ is high, the net interaction is commensal, and the production of DOC specialists increases with increasing particle supply. The prediction that bacterial production in the free-living community is enhanced by increased POC supply is supported by earlier observations (Friedrich et al. 1999, Grossart et al. 2003). Furthermore, the predicted net negative effect on DOC specialists is one of the possible explanations for the observation that disappearance of some free-living species occurred during the bloom (Riemann \& Winding 2001).

Chlorophyll a content and turbidity are often used as indices of particle abundance, which influences the interaction between particle-associated and free-living bacteria. However, it is also necessary to examine the 
origin and composition of the particulate (Grossart et al. 2003) and dissolved (Crump et al. 2003) organic matter, as suggested by the prediction that the qualities of POC and DOC are important factors in determining the population dynamics of free-living bacteria. Additionally, because selective mortality rates would also mediate the interactions between particleassociated and free-living bacteria, interactions with protozoan grazers and viruses must also be taken into consideration (Jürgens \& Sala 2000, Riemann et al. 2000, Artolozaga et al. 2002). We considered the production by each group separately because, if the freeliving cells of DOC specialists and generalists were to be attacked by different predators or viruses, the production of each group, not the whole free-living community, would influence the higher trophic levels. Thus, different patterns of changes in production within the free-living community would lead to different changes in community structure at higher trophic levels. In addition, the question of how each fraction of bacterial production, of 3 different functional groups, influences the whole biochemical cycle in aquatic ecosystems warrants further empirical and theoretical investigation.

Acknowledgements. We thank the members of our mathematical ecology seminar and our microbial ecology seminar, especially Y. Kobayashi, T. Yokokawa, and Dr. T. Nagata, for their valuable suggestions. This study was partly supported by a Grant for Biodiversity Research of the 21st Century COE (A14). T.M. was also partly supported by JSPS Research Fellowships for Young Scientists.

\section{LITERATURE CITED}

Acinas SG, Rodriguez-Valera F, Pedrós-Alió C (1997) Spatial and temporal variation in marine bacterioplankton diversity as shown by RFLP fingerprinting of PCR amplified 16S rDNA. FEMS Microbiol Ecol 24:27-40

Artolozaga I, Valcárcel M, Ayo B, Latatu A, Iriberri J (2002) Grazing rates of bacterivorous protists inhabiting diverse marine planktonic microenvironments. Limnol Oceanogr 47:42-150

Ayo B, Unanue M, Azúa I, Gorsky G, Turley C, Iriberri J (2001) Kinetics of glucose and amino acid uptake by attached and free-living marine bacteria in oligotrophic waters. Mar Biol 138:1071-1076

Barbara GM, Mitchell JG (2003) Marine bacterial organisation around point-like sources of amino acids. FEMS Microbiol Ecol 43:99-109

Cottrell MT, Kirchman DL (2000) Natural assemblages of marine proteobacteria and members of the CytophagaFlavobacter cluster consuming low- and high-molecularweight dissolved organic matter. Appl Environ Microbiol 66:1692-1697

Crump BC, Armbrust EV, Baross JA (1999) Phylogenetic analysis of particle-attached and free-living bacterial communities in the Columbia River, its estuary, and the adjacent coastal ocean. Appl Environ Mirobiol 65:3192-3204

Crump BC, Kling GW, Bahr M, Hobbie JE (2003) Bacterio- plankton community shifts in an arctic lake correlate with seasonal changes in organic matter source. Appl Environ Microbiol 69:2253-2268

del Giorgio PA, Cole JJ (2000) Bacterial energetics and growth efficiency. In: Kirchman DL (ed) Microbial ecology of the oceans. Wiley-Liss, New York, p 289-326

DeLong EF, Franks DG, Alldredge AL (1993) Phylogenetic diversity of aggregate-attached vs free-living marine bacterial assemblages. Limnol Oceanogr 38:924-934

Ducklow H (2000) Bacterial production and biomass in the oceans. In: Kirchman DL (ed) Microbial ecology of the oceans. Wiley-Liss, New York, p 85-120

Fandino LB, Riemann L, Steward GF, Long RA, Azam F (2001) Variations in bacterial community structure during a dinoflagellate bloom analyzed by DGGE and 16S rDNA sequencing. Aquat Microb Ecol 23:119-130

Friedrich U, Schallenberg M, Holliger C (1999) Pelagic bacteria-particle interactions and community-specific growth rates in four lakes along a trophic gradient. Microb Ecol 37:49-61

Grossart HP, Simon M (1998) Bacterial colonization and microbial decomposition of limnetic organic aggregates (lake snow). Aquat Microb Ecol 15:127-140

Grossart HP, Hietanen S, Ploug H (2003) Microbial dynamics on diatom aggregates in Øresund, Denmark. Mar Ecol Prog Ser 249:69-78

Hollibaugh JT, Wong PS, Murrell MC (2000) Similarity of particle-associated and free-living bacterial communities in northern San Francisco Bay, California. Aquat Microb Ecol 21:103-114

Jacobsen TR, Azam F (1984) Role of bacteria in copepod fecal pellet decomposition: colonization, growth rates and mineralization. Bull Mar Sci 35:495-502

Jürgens K, Sala MM (2000) Predation-mediated shifts in size distribution of microbial biomass and activity during detritus decomposition. Oikos 91:29-40

Karner M, Herndl GJ (1992) Extracellular emzymatic-activity and secondary production in free-living and marinesnow-associated bacteria. Mar Biol 113:341-347

Kiørboe T, Jackson GA (2001) Marine snow, organic plumes, and optimal chemosensory behavior of bacteria. Limnol Oceanogr 46:1309-1318

Kiørboe T, Grossart HP, Ploug H, Tang K (2002) Mechanisms and rates of bacterial colonization of sinking aggregates. Appl Environ Mirobiol 68:3996-4006

Kirchman DL (2000) Uptake and regeneration of inorganic nutrients by marine heterotrophic bacteria. In: Kirchman DL (ed) Microbial ecology of the oceans. Wiley-Liss, New York, p 261-288

Kirchman DL (2002) The ecology of Cytophaga-Flavobacteria in aquatic environments. FEMS Microbiol Ecol 39:91-100

Levin SA (1970) Community equilibria and stability, and an extension of the competitive exclusion principle. Am Nat 104:413-423

Middelboe M, Jørgensen NOG, Kroer N (1996) Effects of viruses on nutrient turnover and growth efficiency of noninfected marine bacterioplankton. Appl Environ Microbiol 62:1991-1997

Nagata T, Kirchman DL (1991) Release of dissolved free and combined amino-acids by bacterivorous marine flagellates. Limnol Oceanogr 36:433-443

Nagata T, Kirchman DL (1992) Release of macromolecular organic-complexes by heterotrophic marine flagellates. Mar Ecol Prog Ser 83:233-240

Noble RT, Middelboe M, Fuhrman JA (1999) Effects of viral enrichment on the mortality and growth of heterotrophic bacterioplankton. Aquat Microb Ecol 18:1-13 
Pernthaler J, Glöckner FO, Unterholzner S, Alfreider A, Psenner R, Amann R (1998) Seasonal community and population dynamics of pelagic bacteria and archaea in a high mountain lake. Appl Environ Microbiol 64:4299-4306

Pinhassi J, Azam F, Hemphälä J, Long RA, Martinez J, Zweifel UL, Hagström Å (1999) Coupling between bacterioplankton species composition, population dynamics, and organic matter degradation. Aquat Microb Ecol 17: $13-26$

Riemann L, Winding A (2001) Community dynamics of freeliving and particle-associated bacterial assemblages during a freshwater phytoplankton bloom. Microb Ecol 42: 274-285

Riemann L, Steward GF, Azam F (2000) Dynamics of bacterial community composition and activity during a mesocosm diatom bloom. Appl Environ Microbiol 66:578-587

Schweitzer B, Huber I, Amann R, Ludwig W, Simon M (2001) $\alpha$ - and $\beta$-proteobacteria control the consumption and release of amino acids on lake snow aggregates. Appl Environ Microbiol 67:632-645

Selje N, Simon M (2003) Composition and dynamics of particle-associated and free-living bacterial communities in the Weser estuary, Germany. Aquat Microb Ecol 30: 221-237
Smith DC, Simon M, Alldredge AL, Azam F (1992) Intense hydrolytic enzyme activity on marine aggregates and implications for rapid particle dissolution. Nature 359: 139-142

Smith HL, Waltman P (1995) The theory of the chemostat. Cambridge University Press, New York

Strom SL (2000) Bacterivory: interactions between bacteria and their grazers. In: Kirchman DL (ed) Microbial ecology of the oceans. Wiley-Liss, New York, p 351-386

Unanue M, Ayo B, Azúa I, Barcina I, Iriberri J (1992) Temporal variability of attached and free-living bacteria in coastal waters. Microb Ecol 23:27-39

Williams PJleB (2000) Heterotrophic bacteria and the dynamics of dissolved organic material. In: Kirchman DL (ed) Microbial ecology of the oceans. Wiley-Liss, New York, p 153-200

Worm J, Gustavson K, Garde K, Borch NH, Søndergaard M (2001) Functional similarity of attached and free-living bacteria during freshwater phytoplankton blooms. Aquat Microb Ecol 25:103-111

Zissi U, Lyberatos G (2001) Partial degradation of $p$-aminoazobenzene by a defined mixed culture of Bacillus subtilis and Stenotrophomonas maltophilia. Biotechnol Bioeng 72: $49-54$

Appendix 1. There are 7 equilibria in regard to bacterial composition. In this appendix, we calculated the carbon concentrations of each compartment for each equilibrium

(1) For the equilibrium where all 3 groups of bacteria are absent $\left(E_{N}\right)$ :

$$
\begin{aligned}
& \mathrm{P}_{\mathrm{N}}^{*}=\left(s_{\mathrm{P}}+t_{\mathrm{DP}} s_{\mathrm{D}}\right)\left[\left(1-t_{\mathrm{PD}} t_{\mathrm{DP}}\right) m_{\mathrm{P}}+m_{\mathrm{V}}\right]^{-1} \\
& \mathrm{D}_{\mathrm{N}}^{*}=\left[\left(1-t_{\mathrm{PD}} t_{\mathrm{DP}}\right) m_{\mathrm{P}}+m_{\mathrm{V}}\right]^{-1} m_{\mathrm{D}}{ }^{-1}\left[t_{\mathrm{PD}} s_{\mathrm{P}}+\left(m_{\mathrm{P}}+m_{\mathrm{V}}\right) s_{\mathrm{D}}\right] \\
& \mathrm{F}_{\mathrm{D}, \mathrm{N}^{*}}=\mathrm{F}_{\mathrm{P}, \mathrm{N}^{*}}=\mathrm{F}_{\mathrm{G}, \mathrm{N}^{*}}=0 \\
& \mathrm{~A}_{\mathrm{P}, \mathrm{N}}{ }^{*}=\mathrm{A}_{\mathrm{G}, \mathrm{N}^{*}}=0
\end{aligned}
$$

\section{(2) For the equilibrium where only DOC specialists exist $\left(E_{\mathrm{D}}\right)$ :}

$$
\begin{aligned}
& \mathrm{P}_{\mathrm{D}}^{*}=\left(m_{\mathrm{P}}+m_{\mathrm{V}}\right)^{-1}\left(s_{\mathrm{P}}+u_{\mathrm{D}}^{-1} t_{\mathrm{PD}} m_{\mathrm{D}} m_{\mathrm{F}}+r_{\mathrm{P}} m_{\mathrm{F}} \mathrm{F}_{\mathrm{D}, \mathrm{D}}{ }^{*}\right) \\
& \mathrm{D}_{\mathrm{D}}^{*}=m_{\mathrm{F}} u_{\mathrm{D}}^{-1} \\
& \mathrm{~F}_{\mathrm{D}, \mathrm{D}}^{*}=m_{\mathrm{F}}^{-1}\left[e_{\mathrm{D}}^{-1}-r_{\mathrm{D}}-r_{\mathrm{P}} t_{\mathrm{PD}} m_{\mathrm{P}}\left(m_{\mathrm{P}}+m_{\mathrm{V}}\right)^{-1}\right]^{-1}\left\{t_{\mathrm{PD}} S_{\mathrm{P}} m_{\mathrm{P}}\left(m_{\mathrm{P}}+m_{\mathrm{V}}\right)^{-1}+s_{\mathrm{D}}-u_{\mathrm{D}}{ }^{-1} m_{\mathrm{D}} m_{\mathrm{F}}\left[1-t_{\mathrm{PD}} t_{\mathrm{DP}} m_{\mathrm{P}}\left(m_{\mathrm{P}}+m_{\mathrm{V}}\right)^{-1}\right]\right\} \\
& \mathrm{F}_{\mathrm{P}, \mathrm{D}}{ }^{*}=\mathrm{F}_{\mathrm{G}, \mathrm{D}}{ }^{*}=0 \\
& \mathrm{P}_{\mathrm{P}, \mathrm{D}}^{*}=\mathrm{P}_{\mathrm{G}, \mathrm{D}}{ }^{*}=0
\end{aligned}
$$

(3) For the equilibrium where only generalists exist $\left(E_{\mathrm{G}}\right)$ :

$$
\begin{aligned}
& \mathrm{D}_{\mathrm{G}}{ }^{*}=u_{\mathrm{G}}{ }^{-1}\left\{k^{-1} a_{\mathrm{G}} \mathrm{P}_{\mathrm{G}}{ }^{*}\left[1-h\left(h+m_{\mathrm{A}}+m_{\mathrm{V}}\right)^{-1}\left(1+k e_{\mathrm{P}} f_{\mathrm{F}}\right)\right]+m_{\mathrm{F}}\right\} \\
& \mathrm{F}_{\mathrm{G}, \mathrm{G}^{*}}=\left\{a^{\prime}{ }_{\mathrm{G}} \mathrm{P}_{\mathrm{G}}{ }^{*}\left[1-\left(h+m_{\mathrm{A}}+m_{\mathrm{V}}\right)^{-1} m_{\mathrm{A}}\left(1+k^{-1} r_{\mathrm{P}}\right)\right]-m_{\mathrm{F}} r_{\mathrm{P}}\right\}^{-1} \\
& \times\left(s_{\mathrm{P}}-\left(m_{\mathrm{P}}+m_{\mathrm{V}}\right) \mathrm{P}_{\mathrm{G}}{ }^{*}+t_{\mathrm{DP}} m_{\mathrm{D}} u_{\mathrm{G}}{ }^{-1}\left\{k^{-1} a^{\prime}{ }_{\mathrm{G}} \mathrm{P}_{\mathrm{G}}{ }^{*}\left[1-h\left(h+m_{\mathrm{A}}+m_{\mathrm{V}}\right)^{-1}\left(1+k e_{\mathrm{P}} f_{\mathrm{F}}\right)\right]+m_{\mathrm{F}}\right\}\right) \\
& \mathrm{F}_{\mathrm{P}, \mathrm{G}}{ }^{*}=\mathrm{F}_{\mathrm{D}, \mathrm{G}}{ }^{*}=0 \\
& \mathrm{~A}_{\mathrm{G}, \mathrm{G}}{ }^{*}=k^{-1} a^{\prime}{ }_{\mathrm{G}}\left(h+m_{\mathrm{A}}+m_{\mathrm{V}}\right)^{-1} \mathrm{P}_{\mathrm{G}}{ }^{*} \times \mathrm{F}_{\mathrm{G}, \mathrm{G}}{ }^{*} \\
& \mathrm{~A}_{\mathrm{P}, \mathrm{G}}{ }^{*}=0
\end{aligned}
$$


Appendix 1 (continued)

$$
\begin{aligned}
\alpha= & \left\{t_{\mathrm{PD}} m_{\mathrm{P}}-m_{\mathrm{D}} a^{\prime}{ }_{\mathrm{G}}\left(u_{\mathrm{G}} k\right)^{-1}\left[1-h\left(h+m_{\mathrm{A}}+m_{\mathrm{V}}\right)^{-1}\left(1+k e_{\mathrm{P}} f_{\mathrm{F}}\right)\right]\right\} \times\left\{a_{\mathrm{G}}{ }\left[1-\left(h+m_{\mathrm{A}}+m_{\mathrm{V}}\right)^{-1}\left(m_{\mathrm{A}}+m_{\mathrm{A}} r_{\mathrm{P}} k^{-1}\right)\right]\right\} \\
& +\left\{t_{\mathrm{DP}} m_{\mathrm{D}} a^{\prime}{ }_{\mathrm{G}}\left(u_{\mathrm{G}} k\right)^{-1}\left[1-h\left(h+m_{\mathrm{A}}+m_{\mathrm{V}}\right)^{-1}\left(1+k e_{\mathrm{P}} f_{\mathrm{F}}\right)\right]-\left(m_{\mathrm{P}}+m_{\mathrm{V}}\right)\right\} \\
& \times\left\{a^{\prime}{ }_{\mathrm{G}} k^{-1}\left(h+m_{\mathrm{A}}+m_{\mathrm{V}}\right)^{-1}\left(k f_{\mathrm{D}} h+r_{\mathrm{D}} m_{\mathrm{A}}\right)-a^{\prime}{ }_{\mathrm{G}}\left(e_{\mathrm{D}} k\right)^{-1}\left[1-h\left(h+m_{\mathrm{A}}+m_{\mathrm{V}}\right)^{-1}\left(1+k e_{\mathrm{P}} f_{\mathrm{F}}\right)\right]\right\} \\
\beta= & \left\{t_{\mathrm{PD}} m_{\mathrm{P}}-m_{\mathrm{D}} a^{\prime}{ }_{\mathrm{G}}\left(u_{\mathrm{G}} k\right)^{-1}\left[1-h\left(h+m_{\mathrm{A}}+m_{\mathrm{V}}\right)^{-1}\left(1+k e_{\mathrm{P}} f_{\mathrm{F}}\right)\right]\right\}\left(-r_{\mathrm{P}} m_{\mathrm{F}}\right)+\left\{a_{\mathrm{G}}^{\prime}\left[1-\left(h+m_{\mathrm{A}}+m_{\mathrm{V}}\right)^{-1} m_{\mathrm{A}}\left(1+k^{-1} r_{\mathrm{P}}\right)\right]\right\}\left(s_{\mathrm{D}}-m_{\mathrm{D}} m_{\mathrm{F}} u_{\mathrm{G}}{ }^{-1}\right) \\
& +\left\{t_{\mathrm{DP}} m_{\mathrm{D}} a^{\prime}{ }_{\mathrm{G}}\left(u_{\mathrm{G}} k\right)^{-1}\left[1-h\left(h+m_{\mathrm{A}}+m_{\mathrm{V}}\right)^{-1}\left(1+k e_{\mathrm{P}} f_{\mathrm{F}}\right)\right]-\left(m_{\mathrm{P}}+m_{\mathrm{V}}\right)\right\} \times\left[\left(r_{\mathrm{D}}-e_{\mathrm{D}}{ }^{-1}\right) m_{\mathrm{F}}\right]+\left\{a_{\mathrm{G}}{ }^{-1}\left(h+m_{\mathrm{A}}+m_{\mathrm{V}}\right)^{-1}\left(k f_{\mathrm{D}} h+r_{\mathrm{D}} m_{\mathrm{A}}\right)\right. \\
& \left.-a_{\mathrm{G}}^{\prime}\left(e_{\mathrm{D}} k\right)^{-1}\left[1-h\left(h+m_{\mathrm{A}}+m_{\mathrm{V}}\right)^{-1}\left(1+k e_{\mathrm{P}} f_{\mathrm{F}}\right)\right]\right\} \times\left(s_{\mathrm{P}}+t_{\mathrm{DP}} m_{\mathrm{D}} m_{\mathrm{F}} u_{\mathrm{G}}{ }^{-1}\right) \\
\gamma= & m_{\mathrm{F}}\left(-e_{\mathrm{D}}{ }^{-1}+r_{\mathrm{D}}\right)\left(s_{\mathrm{P}}+u_{\mathrm{G}}{ }^{-1} t_{\mathrm{DP}} m_{\mathrm{D}} m_{\mathrm{F}}\right)-r_{\mathrm{P}} m_{\mathrm{F}}\left(s_{\mathrm{D}}-u_{\mathrm{G}}{ }^{-1} m_{\mathrm{D}} m_{\mathrm{F}}\right)
\end{aligned}
$$

(4) For the equilibrium where only POC specialists exist $\left(E_{\mathrm{p}}\right)$ :

$$
\begin{aligned}
& \mathrm{P}_{\mathrm{P}}^{*}=a_{\mathrm{P}}^{-1} k m_{\mathrm{F}}\left[h\left(h+m_{\mathrm{A}}+m_{\mathrm{V}}\right)^{-1}\left(1+k e_{\mathrm{P}} f_{\mathrm{F}}\right)-1\right] \\
& \mathrm{D}_{\mathrm{P}}^{*}=m_{\mathrm{D}}{ }^{-1}\left\{a_{\mathrm{P}}{ }_{\mathrm{P}} \mathrm{P}_{\mathrm{P}}{ }^{*}\left[1-\left(h+m_{\mathrm{A}}+m_{\mathrm{V}}\right)^{-1} m_{\mathrm{A}}\left(1+k^{-1} r_{\mathrm{P}}\right)\right]-r_{\mathrm{P}} m_{\mathrm{F}}-t_{\mathrm{DP}}\left[\left(h+m_{\mathrm{A}}+m_{\mathrm{V}}\right)^{-1} a_{\mathrm{P}}^{\prime}\left(f_{\mathrm{D}} h+k^{-1} r_{\mathrm{D}} m_{\mathrm{A}}\right) \mathrm{P}_{\mathrm{P}}{ }^{*}+r_{\mathrm{D}} m_{\mathrm{F}}\right]\right\}^{-1} \\
& \times\left(\left[\left(h+m_{\mathrm{A}}+m_{\mathrm{V}}\right)^{-1} a_{\mathrm{P}}^{\prime}\left(f_{\mathrm{D}} h+k^{-1} r_{\mathrm{D}} m_{\mathrm{A}}\right) \mathrm{P}_{\mathrm{P}}^{*}+r_{\mathrm{D}} m_{\mathrm{F}}\right]\left[s_{\mathrm{P}}-\left(m_{\mathrm{P}}+m_{\mathrm{V}}\right) \mathrm{P}_{\mathrm{P}}^{*}\right]\right. \\
& \left.\left.+\left(s_{\mathrm{D}}+t_{\mathrm{PD}} m_{\mathrm{P}} \mathrm{P}_{\mathrm{P}}^{*}\right)\left\{a_{\mathrm{P}}^{\prime} \mathrm{P}_{\mathrm{P}}{ }^{*}\left[1-m_{\mathrm{A}}\left(h+m_{\mathrm{A}}+m_{\mathrm{V}}\right)^{-1}\left(1+k^{-1} r_{\mathrm{P}}\right)\right]-r_{\mathrm{P}} m_{\mathrm{F}}\right\}\right]\right) \\
& \mathrm{F}_{\mathrm{P}_{1} \mathrm{P}}{ }^{*}=\left\{a_{\mathrm{P}}^{\prime} \mathrm{P}_{\mathrm{P}}{ }^{*}\left[1-\left(h+m_{\mathrm{A}}+m_{\mathrm{V}}\right)^{-1}\left(1+k^{-1} r_{\mathrm{P}}\right) m_{\mathrm{A}}\right]-r_{\mathrm{P}} m_{\mathrm{F}}\right\}^{-1} \times\left[s_{\mathrm{P}}-\left(m_{\mathrm{P}}+m_{\mathrm{V}}\right) \mathrm{P}_{\mathrm{P}}{ }^{*}+t_{\mathrm{DP}} m_{\mathrm{D}} \mathrm{D}_{\mathrm{P}}{ }^{*}\right] \\
& \mathrm{F}_{\mathrm{D}, \mathrm{P}^{*}}=\mathrm{F}_{\mathrm{G}, \mathrm{P}^{*}}=0 \\
& \mathrm{~A}_{\mathrm{P}_{\mathrm{f}} \mathrm{P}^{*}}=k^{-1} a_{\mathrm{P}}^{\prime}\left(h+m_{\mathrm{A}}+m_{\mathrm{V}}\right)^{-1} \mathrm{P}_{\mathrm{P}}{ }^{*} \times \mathrm{F}_{\mathrm{P}, \mathrm{P}}{ }^{*} \\
& \mathrm{~A}_{\mathrm{G}, \mathrm{P}^{*}}=0
\end{aligned}
$$

(5) For the equilibrium where DOC specialists and POC specialists coexist $\left(E_{\mathrm{XD}}\right)(\mathrm{X}=\mathrm{G})$ :

$$
\begin{aligned}
& \mathrm{P}_{\mathrm{XD}}^{*}=a^{\prime}{ }^{-1} k m_{\mathrm{F}}\left[\left(h+m_{\mathrm{A}}+m_{\mathrm{V}}\right)^{-1} h\left(1+k e_{\mathrm{P}} f_{\mathrm{F}}\right)-1\right]^{-1}\left(1-u_{\mathrm{D}}{ }^{-1} u_{\mathrm{X}}\right) \\
& \mathrm{D}_{\mathrm{XD}}^{*}=u_{\mathrm{D}}^{-1} m_{\mathrm{F}} \\
& \mathrm{F}_{\mathrm{D}, \mathrm{XD}}{ }^{*}=m_{\mathrm{F}}{ }^{-1}\left(e_{\mathrm{D}}{ }^{-1}-r_{\mathrm{D}}\right)^{-1}\left\{s_{\mathrm{D}}+t_{\mathrm{PD}} m_{\mathrm{P}} \mathrm{P}_{\mathrm{XD}}{ }^{*}-m_{\mathrm{D}} \mathrm{D}_{\mathrm{XD}}{ }^{*}+\left[a_{\mathrm{X}}^{\prime}\left(f_{\mathrm{D}} h+k^{-1} r_{\mathrm{D}} m_{\mathrm{A}}\right)\left(h+m_{\mathrm{A}}+m_{\mathrm{V}}\right)^{-1} \mathrm{P}_{\mathrm{XD}}{ }^{*}-u_{\mathrm{X}} \mathrm{D}_{\mathrm{XD}}{ }^{*}+r_{\mathrm{D}} m_{\mathrm{F}}\right] \mathrm{F}_{\mathrm{X}, \mathrm{XD}}{ }^{*}\right\} \\
& \mathrm{F}_{\mathrm{X}, \mathrm{XD}}{ }^{*}=\left\{a_{\mathrm{X}}^{\prime}\left[1-\left(h+m_{\mathrm{A}}+m_{\mathrm{V}}\right)^{-1} m_{\mathrm{A}}\left(1+k^{-1} r_{\mathrm{P}}\right)\right] \mathrm{P}_{\mathrm{XD}}{ }^{*}-r_{\mathrm{P}} m_{\mathrm{F}}-r_{\mathrm{P}}\left(e_{\mathrm{D}}{ }^{-1}-r_{\mathrm{D}}\right)^{-1}\left[a^{\prime}{ }_{\mathrm{X}}\left(h+m_{\mathrm{A}}+m_{\mathrm{V}}\right)^{-1}\left(f_{\mathrm{D}} h+k^{-1} r_{\mathrm{D}} m_{\mathrm{A}}\right) \mathrm{P}_{\mathrm{XD}}{ }^{*}-u_{\mathrm{X}} \mathrm{D}_{\mathrm{XD}}{ }^{*}+r_{\mathrm{D}} m_{\mathrm{F}}\right]\right\}^{-1} \\
& \times\left[s_{\mathrm{P}}-\left(m_{\mathrm{P}}+m_{\mathrm{A}}\right) \mathrm{P}_{\mathrm{XD}}{ }^{*}+t_{\mathrm{DP}} m_{\mathrm{D}} \mathrm{D}_{\mathrm{XD}}^{*}+r_{\mathrm{P}}\left(e_{\mathrm{D}}^{-1}-r_{\mathrm{D}}\right)^{-1}\left(s_{\mathrm{D}}+t_{\mathrm{PD}} m_{\mathrm{P}} \mathrm{P}_{\mathrm{XD}}^{*}-m_{\mathrm{D}} \mathrm{D}_{\mathrm{XD}}^{*}\right)\right] \\
& \mathrm{A}_{\mathrm{X}, \mathrm{XD}}{ }^{*}=k^{-1} a_{\mathrm{X}}{ }_{\mathrm{X}}\left(h+m_{\mathrm{A}}+m_{\mathrm{V}}\right)^{-1} \mathrm{P}_{\mathrm{XD}}{ }^{*} \times \mathrm{F}_{\mathrm{X}, \mathrm{XD}}{ }^{*}
\end{aligned}
$$

(6) For the equilibrium where DOC specialists and POC specialists coexist $\left(E_{\mathrm{XD}}\right)(\mathrm{X}=\mathrm{P})$ :

we can calculate the equilibrium using the same equations as those for $E_{\mathrm{GD}}$ (Eq. 5), noting that we set $u_{\mathrm{p}}=0$.

(7) For the equilibrium where generalists and POC specialists coexist ( $\left.E_{\mathrm{GP}}\right)$ :

$$
\begin{aligned}
& \mathrm{P}_{\mathrm{GP}}{ }^{*}=a_{\mathrm{P}}^{\prime-1} k m_{\mathrm{F}}\left[\left(h+m_{\mathrm{A}}+m_{\mathrm{V}}\right)^{-1} h\left(1+k e_{\mathrm{P}} f_{\mathrm{F}}\right)-1\right]^{-1} \\
& \mathrm{D}_{\mathrm{GP}}{ }^{*}=u_{\mathrm{G}}{ }^{-1}\left\{a_{\mathrm{G}}^{\prime} k^{-1}\left[1-\left(h+m_{\mathrm{A}}+m_{\mathrm{V}}\right)^{-1} h\left(1+k e_{\mathrm{P}} f_{\mathrm{F}}\right)\right] \mathrm{P}_{\mathrm{GP}}{ }^{*}+m_{\mathrm{F}}\right\} \\
& \mathrm{F}_{\mathrm{D}, \mathrm{GP}}{ }^{*}=0 \\
& \left(\begin{array}{c}
\mathrm{F}_{\mathrm{P}, \mathrm{GP}}{ }^{*} \\
\mathrm{~F}_{\mathrm{G}, \mathrm{GP}}{ }^{*}
\end{array}\right)=(A D-B C)^{-1}\left(\begin{array}{cc}
D & -B \\
-C & A
\end{array}\right)\left(\begin{array}{l}
X \\
Y
\end{array}\right)
\end{aligned}
$$

where

$$
\begin{aligned}
& A=a_{\mathrm{P}}^{\prime}\left[1-\left(h+m_{\mathrm{A}}+m_{\mathrm{V}}\right)^{-1}\left(1+k^{-1} r_{\mathrm{P}}\right) m_{\mathrm{A}}\right] \mathrm{P}_{\mathrm{GP}}{ }^{*}-r_{\mathrm{P}} m_{\mathrm{F}} \\
& B=a_{\mathrm{G}}^{\prime}\left[1-\left(h+m_{\mathrm{A}}+m_{\mathrm{V}}\right)^{-1}\left(1+k^{-1} r_{\mathrm{P}}\right) m_{\mathrm{A}}\right] \mathrm{P}_{\mathrm{GP}}{ }^{*}-r_{\mathrm{P}} m_{\mathrm{F}} \\
& C=a_{\mathrm{P}}^{\prime}\left(f_{\mathrm{D}} h+k^{-1} r_{\mathrm{D}} m_{\mathrm{A}}\right) \mathrm{P}_{\mathrm{GP}}{ }^{*}+r_{\mathrm{D}} m_{\mathrm{F}} \\
& D=a_{\mathrm{G}}{ }\left(f_{\mathrm{D}} h+k^{-1} r_{\mathrm{D}} m_{\mathrm{A}}\right) \mathrm{P}_{\mathrm{GP}}{ }^{*}+r_{\mathrm{D}} m_{\mathrm{F}}-u_{\mathrm{G}} \mathrm{D}_{\mathrm{GP}}{ }^{*} \\
& X=s_{\mathrm{P}}-\left(m_{\mathrm{P}}+m_{\mathrm{V}}\right) \mathrm{P}_{\mathrm{GP}}{ }^{*}+t_{\mathrm{DP}} m_{\mathrm{D}} \mathrm{D}_{\mathrm{GP}}{ }^{*} \\
& Y=-s_{\mathrm{D}}-t_{\mathrm{PD}} m_{\mathrm{P}} \mathrm{P}_{\mathrm{GP}}{ }^{*}+m_{\mathrm{D}} \mathrm{D}_{\mathrm{GP}}{ }^{*} \\
& \mathrm{~A}_{\mathrm{P}, \mathrm{GP}}{ }^{*}=k^{-1} a_{\mathrm{P}}\left(h+m_{\mathrm{A}}+m_{\mathrm{V}}\right)^{-1} \mathrm{P}_{\mathrm{GP}}{ }^{*} \times \mathrm{F}_{\mathrm{P}, \mathrm{GP}}{ }^{*} \\
& \mathrm{~A}_{\mathrm{G}, \mathrm{GP}}{ }^{*}=k^{-1} a_{\mathrm{G}}\left(h+m_{\mathrm{A}}+m_{\mathrm{V}}\right)^{-1} \mathrm{P}_{\mathrm{GP}}{ }^{*} \times \mathrm{F}_{\mathrm{G}, \mathrm{GP}}{ }^{*}
\end{aligned}
$$

